\title{
DAMPAK MODEL BIMBINGAN DAN KONSELING ISLAM TERHADAP PERILAKU KEAGAMAAN MUALLAF DI PUSAT REHABILITASI AQIDAH
}

\author{
Tri Susilo Sigit Sujarwo \\ Program Studi Komunikasi dan Konseling Islam \\ Program Pasca Sarjana \\ Universitas Muhammadiyah Yogyakarta \\ E-mail: sujarwo.sigit@yahoo.co.id
}

\begin{abstract}
Abstrak
Penelitian ini bertujuan: (1) mengetahui model bimbingan dan konseling Islam terhadap muallaf pada masa sebelum dan sesudah melakukan konversi agama; (2) mengetahui dampak dari bimbingan dan konseling Islam terhadap perilaku keagamaan muallaf di Pusat Rehabilitasi Aqidah. Jenis penelitian yang peneliti gunakan adalah penelitian deskriptif kualitatif. Adapun lokasi yang peneliti pilih adalah Pusat Rehabilitasi Aqidah yang beralamat di komplek Pondok Pesantren Al Hadid Karangmojo Kapubaten Gunung Kidul Popinsi DIY. Teknik pengumpulan datanya menggunakan metode observasi, wawancara dan dokumentasi. Berdasarkan hasil penelitian, dapat peneliti simpulkan: (1) model bimbingan konseling Islam terhadap muallaf berasrama dan dimulai sejak pra konversi sampai pasca konversi agama. (2) dampak dari bimbingan dan konseling Islam terhadap muallaf yang dilakukan oleh Pusat Rehabilitasi Aqidah berdampak positip terhadap perilaku keagamaan muallaf, karena dilakukan secara profesional dan dengan hati yang ikhlas sehingga membantu muallaf untuk bisa melaksanakan kewajibannya sebagai seorang muslim yang bertaqwa mampu hidup secara mandiri dan bermanfaat bagi sesama.
\end{abstract}

Kata kunci: model bimbingan dan konseling Islam, perilaku keagamaan, muallaf dan dampak konversi agama

\begin{abstract}
This study aims: (1) To know the model of Islamic guidance and counseling of muallaf before and after conversion; (2) to analize the impact of Islamic guidance and counseling on the religious behavior of muallaf at Aqidah Rehabilitation Center. The researcher used descriptive qualitative in his research. The location of this researchers is Rehabilitation Center Aqidah which is located in Al Hadid Islamic boarding school at Karangmojo Gunung Kidul Yogyakarta. The researcher used the observation, interview and documentation method to collect the data. Based on the results of research, the research conclude: (1) Model of Islamic guidance and counseling of muallaf started from pre-conversion until post conversion of religion. (2) The impact of Islamic guidance and counseling of muallaf which conducted by Aqidah Rehabilitation Center on the religious behavior has a positive impact, because, it done professionally and with a sincere that help muallaf to be able to carry his duty out as a real muslim and can live independently and usefulfor a people.
\end{abstract}

Keywords: model islamic guidance and counseling, religious behavior, muallaf and the impact of religious conversion.

\section{Info Artikel}

Diterima September 2017, disetujui Oktober 2017, diterbitkan Desember 2017

Dipublikasikan Oleh: Program Studi Bimbingan dan Konseling 


\section{PENDAHULUAN}

Bulan Juli 2016, Pusat Rehabilitasi Aqidah menangkap seorang muallaf yang menjadikan status muallafnya untuk mencari keuntungan materi dan finansial. Muallaf ini berbekal sertifikat pensyahadatan pergi dari masjid ke masjid atau ke lembaga-lembaga sosial untuk minta santunan, bahkan yang lebih ironis muallaf ini oleh Pusat Rehabilitasi Aqidah pernah ditangkap pada tahun 2007 dengan kasus yang sama. Hal ini menandakan bahwa pembinaan para muallaf tidak berjalan dengan baik.

Kasus lain yang Pusat Rehabilitasi Aqidah tangani mengenai adanya muallaf yang kembali ke agama lamanya (murtad). Pada kasus ini biasanya seseorang yang menjadi muallaf mendapatkan ancaman atau intimidasi dari keluarganya. Peneliti mengetahui sendiri karena peneliti pernah mensyahadatkan seseorang tetapi setelah beberapa bulan menjadi muallaf dan mendapatkan intimadasi dari pihak keluarga, akhirnya muallaf tersebut kembali lagi ke agama semula.

Kejadian maupun kasus-kasus di atas mencerminkan bahwa belum adanya lembaga yang membina para muallaf dengan baik dan efektif. Hal ini juga diakui oleh pemerintah seperti yang dimuat dalam surat kabar Republika online (2014), yang memberitakan bahwa pemerintah dan umat Islam di Indonesia belum serius dalam memberikan perhatian kepada muallaf. Perhatian yang dimaksud di antaranya serius bertanggung jawab dalam pembinaan sekaligus pendanaan terhadap anggota baru dalam komunitas Islam tersebut.

Di Indonesia sendiri, muallaf, sebagaimana dilaporkan Republika online (2014), meningkat 10\%-15\% per tahun. Secara kasar, tahun 2010 muallaf diperkirakan lebih dari 1 juta orang. Angka ini tentu saja cukup tinggi tetapi belum terbina dengan baik, seperti disampaikan oleh ketua umum Himpunan Bina Muallaf Indonesia (HBMI), Syarif S. Tanudjaja seperti dilansir Republika online (2014) mengatakan saat ini proses pembinaan muallaf masih berdiri sendiri dan belum profesional. Untuk itu diperlukan program pembinaan muallaf secara naisonal. Pembinaan terhadap muallaf saat ini belum terstruktur dengan baik. Tidak ada pembinaan secara jelas tentang materi apa yang harus diberikan kepada muallaf. Selama ini, muallaf hanya diajarkan tentang spiritualitas dan ritual-ritual dasar keagamaan. Misalnya, cara shalat dan pemahaman terhadap rukun Islam atau rukun iman sebagai dasar keislaman. Seorang muallaf harus juga dipahami latar belakang intelektualnya.

Persoalan lain terkait pembinaan muallaf adalah konteks sosial, ekonomi, dan kultural dari muallaf. Mereka berada dalam lingkungan baru dan harus meninggalkan keluarga dan kultur mereka sebelumnya. Mungkin juga mereka bermasalah dengan 
persoalan ekonomi. Semua hal tersebut harus menjadi perhatian dalam pembinaan muallaf.

Melakukan konversi agama merupakan suatu peristiwa penting dalam kehidupan seseorang. Menurut Paloutzian Seperti dikutip oleh Subandi (2013: 95) dalam bukunya Psikologi dan Kesehatan Mental, menjelaskan bahwa konversi agama akan membuat seluruh kehidupan seseorang berubah selama-lamanya, karena pada dasarnya konversi agama merupakan perubahan mendasar dan penataan ulang identitas diri, makna hidup juga aktivitas seseorang.

Keputusan untuk melakukan konversi ke Islam bukanlah hal sepele. Proses seseorang mengambil keputusan untuk berkonversi melalui tahapan yang panjang. Daradjat (2003: 38) menyebutkan bahwa proses konversi agama melalui lima tahapan proses kejiwaan, yaitu; (1) masa tenang; (2) masa ketidaktenangan; (3) masa konversi; (4) masa tenang dan tenteram; dan (5) masa ekspresi konversi. Sementara itu proses konversi menurut Carrier dalam bukunya Jalaludin yang berjudul Psikologi Agama (2002: 352) tahapantahapan konversi agama berikut; (1) Terjadinya disintegrasi sintesis kognitif dan motivasi sebagai akibat dari krisis yang dialami; Reintegrasi kepribadian berdasarkan konversi agama yang baru. Dengan adanya reintegrasi ini maka terciptalah kepribadian baru yang berlawanan dengan struktur lama; (3) Tumbuh sikap menerima konsepsi agama baru serta peranan yang dituntut oleh ajarannya; (4) Timbul kesadaran bahwa keadaan yang baru itu merupakan panggilan suci petunjuk Tuhan.

Ketika seseorang melakukan konversi agama dan menjadi muallaf, maka muallaf tersebut diharapkan bisa meninggalkan sebagian atau bahkan seluruh nilai, keyakinan dan aturan yang lama. Disaat yang sama, muallaf diharapkan mampu mengetahui tata nilai, sistem perilaku dari agama yang baru dianut, sekaligus menyesuaikan diri, melakukan aktivitas dan pola perilaku yang sesuai. Melakukan konversi agama berarti belajar dan beradaptasi dengan banyak hal tentang berbagai hal yang baru.

Keputusan melakukan konversi agama merupakan keputusan besar dengan konsekuensi yang besar pula. Peristiwa konversi agama tidak hanya membawa konsekuensi personal tapi juga reaksi sosial yang bermacammacam, terutama dari pihak keluarga dan komunitas terdekat. Pada beberapa kasus konversi agama, penghentian dukungan secara finansial, kekerasan secara fisik maupun psikis baik lewat pengacuhan, cemoohan, pengucilan, bahkan sampai pengusiran oleh keluarga kerap dialami oleh seseorang yang melakukan perpindahan agama.

Dilema dan konflik juga seringkali dialami oleh para muallaf ketika dihadapkan pada berbagai keputusan penting secara bersamaan, 
misalnya saat harus memilih agama yang diyakini dan meninggalkan orang tua yang dicintai sebagai konsekuensi pilihannya. Oleh karena itu, seorang muallaf sebagai muslim baru membutuhkan teman, tempat berlindung, juga pembimbing. Orangorang yang baru saja hijrah memeluk Islam, membutuhkan sosok teman yang dapat memberikan dukungan moril dan perlindungan dari kecaman keluarga maupun sanak saudaranya yang mampu menggoyahkan konsistensinya dalam beragama.

Menyikapi hal tersebut, peneliti tegaskan bahwa bimbingan konseling Islam terhadap muallaf merupakan suatu keharusan bagi lembaga dakwah maupun organisasi masyarakat keagamaan. Faktor itulah yang masih menjadi persoalan utama sampai saat ini masih belum terlaksana dengan baik. Pengislaman atau pensyahdatan terhadap seseorang yang mau masuk Islam sudah dilaksanakan di masjidmasjid besar di seluruh Indonesia, namun setelah proses pengislaman jarang ada tindak lanjutnya atau pembinaannya. Pengurus Masjid atau lembaga yang mengislamkan muallaf seharusnya tidak sekedar mengeluarkan sertifikat pensyahadatan tetapi sebaiknya terus menjalin hubungan yang berkelanjutan dengan para mullaf untuk dilakukan bimbingan dan pembinaan.

Berkaitan dengan hal tersebut, peneliti tertarik untuk meneliti di Pusat Rehabilitasi Aqidah dalam hal model bimbingan dan konseling Islam yang diterapkan terhadap muallaf. Muallaf setelah mengucapkan ikrar dua kalimat syahadat di Pusat Rehabilitasi Aqidah tidak langsung mendapatkan sertifikat muallaf, melainkan wajib mengikuti program bimbingan konseling minimal selama sebulan, tinggal di asrama dan dinyatakan lulus baru mendapatkan sertifikat muallaf. Materi bimbingan dan konseling Islam, meliputi keislaman seperti akidah, fiqh ibadah, akhlak, membaca al-Qur'an dan mendapatkan layanan konseling Islam serta pelatihan wirausaha dari ustadz pembimbing.

Penelitian ini fokus untuk menjawab dua permasalahan yaitu; (1) bagaimana model bimbingan dan konseling Islam terhadap muallaf di Pusat Rehabilitasi Aqidah dan, (2) bagaimana dampak dari bimbingan dan konseling Islam terhadap perilaku keagamaan muallaf. Karena luasnya wilayah kajian penelitian, maka peneliti membatasi masalah sebagai berikut: (1) Model bimbingan dan konseling Islam yang dimaksud dalam penelitian ini adalah segala kegiatan yang berupa bimbingan dan arahan secara operasional kepada para muallaf, baik dalam bentuk pendampingan, pembinaan, pelatihan, diskusi, pengajian maupun pemberdayaan. (2) Perilaku keagamaan muallaf yang dimaksud dalam penelitian ini adalah muallaf mempunyai keteguhan iman, ketaatan dalam beribadah serta berkepribadian yang baik atau berakhlak mulia. 


\section{METODE PENELITIAN}

\section{Jenis dan Pendekatan Penelitian}

Penelitian ini dirancang untuk memperoleh informasi tentang model bimbingan dan konseling Islam serta dampaknya terhadap perilaku keagamaan muallaf di Pusat Rehabilitasi Aqidah. Jenis penelitian ini adalah penelitian kualitatif deskriptif fenomenologi dengan model pendekatan psikologis, mengingat persoalan terbesar dalam proses pembinaan khususnya mereka yang berstatus muallaf adalah masalah konversi dari agama asal ke agama baru yang banyak menimbulkan beban psikis bagi pelaku.

Pendekatan kualitatif ditujukan untuk memahami fenomena-fenomena sosial dari sudut atau persepektif partisipan (Sukmadinata, 2013: 94). Tujuan penelitian biasanya berkaitan dengan hal-hal yang bersifat praktis. Orientasi fenomenologis menekankan aspek subjektif dari tingkah laku manusia (Irawan, 2006: 13). Peneliti tidak menyimpulkan mana yang benar dan mana yang salah namun peneliti berusaha memahami apa terjadi terhadap sebuah fenomena.

\section{Lokasi dan Sumber Data Penelitian}

Penelitian ini dilaksanakan di Pusat Rehabilitasi Aqidah yang berada komplek Pondok Pesantren Al Hadid Karangmojo

Gunungkidul Yogyakarta. Lembaga ini peneliti pilih karena Pusat Rehabilitasi Aqidah merupakan lembaga yang khusus bergerak menangani pembinaan dan pendampingan para muallaf yang sistem pembinaan berjalan dengan baik.

Dalam menentukan sumber data dalam penelitian ini menggunakan purposive sampel, yaitu jenis penentuan subjek dengan menggunakan kriteria tertentu. Jumlah keseluruhan sumber data dalam penelitian ini 8 orang. Pada tahap awal, peneliti menetapkan beberapa orang sebagai informan kunci. Penentuan informan kunci ini penting, mengingat mereka inilah yang sangat mengetahui dan memahami setting penelitian dan juga dapat merekomendasikan orang lain yang dapat menjadi informan selanjutnya (Bungin, 2006: 53).

Pada tahap awal, peneliti menemui sumber data utama penelitian ini yaitu ustadz Yusuf Ismail. Ditetapkannya sutadz Yusuf Ismail sebagai key informan dalam penelitian ini mengingat bahwa ustadz Yusuf merupakan ketua dari Pusat Rehabilitasi Aqidah yang tentunya mengetahui model bimbingan dan konseling Islam yang diterapkan terhadap muallaf di Pusat Rehabilitasi Aqidah. Ustadz Yusuf selanjutnya merekomendasikan 3 orang ustadz pembimbing dan 4 muallaf untuk dijadikan informan penelitian. Khusus sumber data muallaf peneliti memilih 4 subjek muallaf dan menentukan kriteria, diantaranya adalah; (1) Orang yang berpindah dari agama atau kepercayaan lain menjadi pemeluk agama Islam (dibuktikan oleh piagam 
pengesahan agama Islam atau kartu tanda penduduk dan atau kesaksian pihak yang mengetahui). (2) Usia dewasa antara 25 tahun sampai 50 tahun laki-laki maupun perempuan baik yang sudah menikah maupun belum menikah. Peneliti memilih usia dewasa karena menurut Subandi (2013: 98), usia dewasa merupakan usia yang pada umumnya seseorang telah mencapai kemantapan dan kedewasaan, baik secara psikologis, sosial, maupun ekonomis. (3) Muallaf pernah mengikuti program bimbingan dan konseling Islam di Pusat Rehabilitasi Aqidah baik yang masih mengikuti program maupun alumninya.

\section{Teknik Pengumpulan Data}

Melalui teknik pengumpulan data wawancara mendalam (depth interview) atau wawancara tidak terstruktur dan pengamatan partisipasi pasif (passive participation observation), peneliti mengumpulkan dan mencatat dengan cermat setiap informasi mengenai model bimbingan dan konseling Islam terhadap muallaf. Untuk mendapatkan hasil yang optimal peneliti membaur dengan setiap kegiatan yang diadakan oleh Pusat Rehabilitasi Aqidah.

Peneliti juga menjalin keakraban dengan para pembimbing dan muallaf serta keluarga mereka sehingga bisa didapatkan data-data yang lebih akurat. Sebagai teknik pengumpulan data tambahan, peneliti mengumpulkan berbagai dokumen tertulis yang diperoleh dari ustadz Yusuf sebagai ketua Pusat Rehabilitasi Aqidah, dokumen berupa buku catatan harian kegiatan muallaf maupun modul. Selain itu, teknik dokumentasi peneliti lengkapi pula dengan fotofoto dokumentasi kegiatan penelitian.

\section{Teknik Analisis Data}

Pengolahan data dilakukan seiring dengan proses pengumpulan data menggunakan teknik analisis data kualitatif mengikuti konsep yang diberikan Miles \& Huberman, yaitu data collection, data reduction, data display, dan conclutions: drawing/verifying (Miles \& Huberman, 1992: 15). (1) Peneliti mencatat seluruh temuan penelitian baik melalui wawancara, observasi maupun hasil dokumentasi. (2) Menelaah dan memilah data yang terkait dengan fokus penelitian dan disajikan dalam bentuk matriks. (3) Mendeskripsikan dan menelaah data dengan teori-teori yang relevan dalam bentuk laporan akhir penelitian. Untuk menguji keabsahan data khususnya dari aspek kredibelitas data yang telah diperoleh, maka peneliti melakukan beberapa cara, yaitu: triangulasi, pemeriksaan sejawat melalui diskusi (FGD), member check dan uraian rinci.

\section{HASIL DAN PEMBAHASAN Profil Pusat Rehabilitasi Aqidah}

Pusat Rehabilitasi Aqidah berlokasi di kompleks Pondok Pesantren Al Hadid Karangmojo 
Gunung kidul Yogyakarta. Berdasarkan hasil observasi, peneliti melihat langsung dari dekat bahwa Pusat Rehabilitasi Aqidah berdiri di atas tanah wakaf seluas $2000 \mathrm{~m} 2$ yang terdiri dari dua bangunan utama yaitu asrama untuk muallaf putra dan muallaf putri lengkap dengan segala fasilitas termasuk perpustakaan dan aula tempat kegiatan belajar mengajar dan bimbingan dan konseling serta bangunan Mushola dan taman. Muallaf yang mengikuti program bimbingan dan konseling Islam semuanya gratis bahkan dibantu jika membutuhkan keperluan sehari-hari.

Pusat Rehabilitasi Aqidah mempunyai visi menjadi lembaga yang profesional dalam menangani muallaf, sedangkan misinya adalah; (1) menampung, membina, melatih, membimbing dan mengarahkan muallaf, untuk disalurkan sesuai talenta yang dimiliki masing-masing, (2) mendudukkan citra muallaf dalam posisi orang yang lebih baik, sebagai orang yang baru lahir kembali. Tujuan berdirinya Pusat Rehabilitasi Aqidah adalah sebagai berikut: (1) tempat singgah bagi muallaf yang memerlukan tempat tinggal sementara, karena berbagai hal, (2) tempat pembinaan mental, rohani dan pendidikan keislaman, (3) tempat pendidikan dan pelatihan kewirausahaan. (4) tempat rehabilitasi bagi mereka yang pernah murtad dan kemudian kembali ke Islam, (5) pusat pembelaan hukum bagi muallaf yang sering teraniaya oleh keluarga dan lingkungan lamanya, (6) pusat riset dan penelitian tentang muallaf, (7) pusat perpustakaan kristologi.

\section{Model Bimbingan dan Konseling Islam terhadap Muallaf}

Model bimbingan dan konseling Islam terhadap muallaf yang diterapkan di Pusat Rehabilitasi Aqidah tentunya tidaklah dapat disamakan dengan umat Islam pada umumnya. Muallaf datang dari latar belakang keyakinan berbeda yang mungkin mengalami banyak tekanan psikologis sehingga seorang pembimbing atau konselor harus memahami latar belakang seorang muallaf, apakah itu agamanya, budaya, suku, tingkat pendidikan, dan segala hal yang mungkin dapat menjadi penghambat dalam proses pelaksanaan bimbingan dan konseling Islam.

Penerapan konseling Islam di Pusat Rehabilitasi Aqidah menggunakan model konseling spiritual atau konseling religius, model ini digunakan karena sesuai dengan yang ditangani yaitu masalah konversi agama. Muallaf yang mengikuti bimbingan konseling Islam dibedakan menjadi 2, yaitu; pertama, muallaf yang proses masuk Islamnya dilakukan di Pusat Rehabilitasi Aqidah dan kemudian mengikuti program bimbingan konseling, kedua muallaf yang sudah bersyahadat di luar kemudian datang ke Pusat Rehabilitasi Aqidah untuk mengikuti 
program bimbingan dan konseling Islam.

\section{Pra Konversi}

Calon muallaf yang datang ke Pusat Rehabilitasi Aqidah untuk minta di syahadatkan, oleh Pusat Rehabilitasi aqidah tidak langsung disyahadatkan, melainkan harus mengikuti proses tes kemuallafan dan mengikuti program bimbingan dan konseling Islam pra konversi.

Hasil wawancara dengan ustadz pembimbing memberikan informasi bahwa calon muallaf sebelum disyahadatkan akan mengikuti proses tes kemuallafan, tes kemuallafan untuk mengetahui motivasi seseorang mau masuk Islam, selesai tes kemuallafan dan muallaf dinyatakan sungguh-sungguh ikhlas dan mau berislam maka calon muallaf mengikuti bimbingan dan konseling Islam. Bimbingan dan koseling ini dilaksanakan di Pusat Rehabilitasi Aqidah dengan model konseling individual, metode yang digunakan menyesuaikan dengan tipe kepribadian calon muallaf, bisa dengan metode direktif, non direktif atau dengan metode elektif. Bimbingan dan konseling terhadap calon muallaf minimal dilakukan selama seminggu dengan tujuan untuk memantapkan calon muallaf dalam memeluk Islam.

$$
\text { Kegiatan bimbingan dan }
$$

koseling Islam pra syahadat ini meliputi: (1) Calon muallaf diberikan buku yang berjudul Dialog Masalah Ketuhanan Yesus karangan $\mathrm{KH}$.
Bahaudin Mudhary yang diterbitkan oleh Pustaka Dai Surabaya. Buku ini berisi dialog perbandingan agama antara Islam dengan Kristen, dengan uraian bahasa yang santun dan lembut, harapannya calon muallaf setelah membaca buku tersebut semakin mantap dengan keputusannya untuk berislam. (2) Calon muallaf mendapatkan materi bimbingan studi perbandingan agama. Materi ini diperlukan agar calon muallaf meyakini betul Islam sebagai agama yang benar dan harus diyakini. Pada materi ini pembimbing dan calon muallaf diberikan kesempatan untuk berdiskusi dan tanya jawab permasalahan yang berkaitan dengan keyakinan bersadarkan kitab sucinya masing-masing kemudian membandingkannya. (3) Calon muallaf setelah mantap untuk berislam maka tahap selanjutnya adalah bimbingan dasar-dasar keislaman, materi ini bertujuan agar calon muallaf mengetahui konsekuensi setelah menjadi seorang muslim. Materi yang diberikan seperti aqidah, tata cara bersuci dan berwudhu dan tata cara sholat dan bacaannya. Materi ini diberikan kepada calon muallaf agar setelah bersyahadat bisa mengamalkan semampunya. (4) Ditahap ini pula pembimbing melakukan proses konseling sampai calon muallaf benarbenar merasakan ada teman atau saudara yang akan membantu setelah bersyahadat.

Banyak muallaf ketika mau bersayahadat mengalami goncangan 
psikologis. Goncangan psikologis disebabkan karena banyak faktor salah satunya adalah kekhawatiran, misalnya setelah berislam akan diusir oleh keluarganya atau diceraikan oleh pasangannya. Pusat Rehabilitasi Aqidah sudah mengantisipati hal-hal tersebut dan berkomitmen akan mencarikan solusi dan mengadvokasi dari masalah-masalah yang menimpa muallaf setelah bersyahadat. Sebagai contoh, apabila ada muallaf yang diusir dari keluarganya maka akan ditampung di Pusat Rehabilitasi Aqidah atau jika ada muallaf yang mau melakukan perceraian karena salah satunya mendapatkan hidayah Islam maka akan dibantu mengurus perceraiannya sampai selesai termasuk ditanggung biayanya dan dibantu mencarikan tempat tinggal.

\section{Pasca Konversi}

Beberapa hal yang menjadi poin penting serta menjadi bahan referensi dalam proses bimbingan dan konseling Islam muallaf paska syahadat adalah prinsip kemudahan dalam membina seorang muallaf. Hal ini penting karena masih ada beberapa lembaga yang menangani muallaf memberikan pembinaan disamakan dengan kaum muslim yang bukan muallaf padahal muallaf merupakan orang yang baru mengenal Islam. Seorang muallaf tidaklah boleh dibebani dengan sesuatu yang sangat berat yang dapat menyebabkan mereka justru lari dari Islam dan kembali ke agama asalnya.
Model bimbingan dan konseling terhadap muallaf tidaklah dapat disamakan dengan model bimbingan dan konseling terhadap umat Islam yang telah lama berislam. Muallaf membutuhkan penguatan proses keyakinan agar teguh dalam keyakinan barunya. Proses bimbingan dan konseling Islam terhadap muallaf agar berjalan optimal maka muallaf perlu dibagi berdasarkan kategori, kategori tersebut diantaranya: (1) Menurut jenis kelamin (pria dan wanita). (2) Individu atau suami-istri atau satu keluarga lengkap. (3) Kelompok awam atau kelompok mantan pemuka agama seperti pendeta, pastor atau aktivis gereja. (4) Berasal dari agama mana dan sekte agama asalnya. (4) Muallaf yang memang berasal dari luar Islam dan muallaf yang merupakan orang Islam yang pernah dimurtadkan dan dikembalikan ke agama Islam. Dalam kasus ini mereka perlu pembinaan tersendiri dan rehabilitasi. (5) Muallaf yang dapat baca tulis dengan muallaf yang tidak dapat baca tulis. (6) Muallaf warga keturunan terutama keturunan Thionghoa atau muallaf dari masyarakat suku terasing.

Tingkat pendidikan dan sosial ekonomi mereka tidak sama, ada yang awam dan intelektual, ada yang golongan miskin dan ada juga pengusaha sukses bahkan ada pejabat tinggi, oleh karena itu model bimbingan dan konselingnya harus bervariasi. Di Pusat Rehabilitasi Aqidah setelah muallaf disyahadatkan 
maka tidak langsung menerima sertifikat pensyahadatan. Muallaf yang mau menerima sertifikat pensyahadatan harus mengikuti program pembinaan atau bimbingan dan konseling minimal satu bulan dengan model berasrama.

Target bimbingan dan konseling Islam terhadap muallaf peneliti dapatkan dari dokumen berupa modul pelaksanaan pembinaan dan pendampingan muallaf, bahwa target bimbingan dan konseling Islam terhadap muallaf adalah sebagai berikut; (1) muallaf terbimbing dalam hal karakter atau mental dan budayanya. (2) Muallaf terbimbing dalam keyakinannya dan memahami dasar-dasar keislaman dengan baik. Karena dengan memahami dasar-dasar keislaman yang baik muallaf tersebut akan bertambah kemantapannya terhadap kebenaran ajaran Islam. (3) Muallaf terbimbing dan terberdayakan ekonominya. Target ini diperlukan mengingat permasalahan terbesar kurang mandirinya muallaf karena faktor ekonomi, hal inilah yang menyebabkan muallaf terkadang masih memiliki ketergantungan yang tinggi terhadap keluarga mereka yang masih non muslim.

Materi bimbingan dan koseling Islam yang diberikan kepada muallaf adalah materi-materi sebagai berikut: (1) Pendidikan dasar-dasar keislaman seperti aqidah, tatacara bersuci dan berwudhu, tatacara sholat dan ibadah umum lainnya. (2) Membaca alQur'an yang meliputi pembelajaran tajwid, tahsinul qiroah, hafalan surahsurah pendek khususnya untuk bacaan sholat. (3) Pendidikan akhlaqul karimah (model keteladanan yang dicontohkan oleh para ustadz pembimbing). (4) Materi studi perbandingan agama. Materi ini diperlukan agar mereka meyakini betul Islam sebagai agama yang benar dan menyadari agama lamanya sebagai agama yang memang harus ditingalkan. Materi ini dimaksudkan agar muallaf tidak merasa salah telah memilih Islam. (5) Materi pemberdayaan ekonomi, materi ini berbentuk pelatihan seperti pembuatan sabun deterjen, jamu instan dan juga cara bertani dan beternak yang produktif dan benilai ekonomis tinggi dan sampai saat ini sudah berkerjasama dengan Badan Amil Zakat Daerah Propinsi Yogyakarta untuk pengembangan dan pemberdayaan ekonomi muallaf. (6) Pendampingan dan konseling, mengingat banyaknya muallaf yang membawa masalah akibat konvesi agama yang dilakukannya. Selain pendampingan dan koseling materi tentang ruqyah syar'iyah juga diajarkan dan di praktekkan karena mengingat banyak mualllaf terkadang masih membawa hal-hal yang berbau mistik dan kemusrikan ketika masuk Islam. Beberapa kasus ada yang menyimpan jimat yang perlu dihilangkan. Terkadang mereka juga terkena sihir dari komunitas lamanya yang tidak menyenangi karena melakukan konversi agama keislam. 
Metode penyampaian materi bimbingan Islam terhadap muallaf dilakukan dengan metode ceramah, diskusi dan praktek lapangan, untuk pelaksanaanya dilakukan secara klasikal dan terjadwal kecuali yang berkaitan dengan materi konseling Islam yang dilaksanakan secara individual. Khusus untuk metode konseling pembimbing biasanya menerapkan 3 metode dan dalam prakteknya disesuaikan dengan tipe kepribadian muallaf, ke 3 metode tersebut adalah metode direktif, non direktif dan elektif.

\section{Perilaku Keagamaan Muallaf}

Seseorang yang melakukan konversi dari agama dan kepercayaan tertentu menjadi pemeluk agama Islam pasti akan mengalami perubahan disemua aspek kehidupannya baik mental spiritual, budaya dan sosialnya. Perubahan tersebut menuntut muallaf untuk belajar dan beradaptasi dengan banyak hal tentang berbagai hal yang baru. Penelitian ini mengambil 4 muallaf sebagai subjek penelitian untuk menggambarkan realitas perilaku keagamaan muallaf.

\section{Pra Konversi}

Peristiwa konversi agama dan perilaku keagamaan merupakan hasil sekaligus awal baru dari berbagai bentuk interaksi, identifikasi dan penilaian yang berproses dan berlangsung terus menerus. Menurut Mulyono (2007: 39) bahwa calon muallaf yang ingin melakukan konversi agama akan mengalami proses perubahan identitas, perubahan tersebut antara lain: (1) Perkembangan kapasitas kognitif. Perkembangan kognitif yang turut menjadi perantara terjadinya perubahan dan perkembangan perilaku keagamaan pada seseorang yang akan melakukan konversi agama, yaitu meningkatnya rasa ingin tahu dan penasaran (Couriosity and Wonder). Membuat perkiraan dan hipotesis (forecasting). Seseorang yang mau melakukan konversi agama atau calon muallaf tampaknya membuat perkiraan atau membayangkan dengan menjangkau hal-hal yang belum pasti terjadi: "Apa konsekuensi dari sebuah perbuatan?" namun sering kali hal-hal yang dibayangkan oleh calon muallaf terlalu berlebihan (over estimate), sehingga hal ini menambah kecemasan pada dirinya yang menjadi penyebab melakukan konversi agama.

(3) Keterbukaan struktur keyakinan (Permeability). Terbukanya struktur keyakinan calon muallaf merupakan hal yang penting dalam proses terjadinya konversi. (4) Meluasnya spektrum interaksi sosial. Berada di dalam lingkungan yang sebagian besar beragama Islam, secara langsung maupun tidak langsung memberikan pengaruh tersendiri bagi calon muallaf dalam mengenal nilai-nilai Islam.

\section{Pasca Konversi}

Masa konversi agama terjadi dalam waktu yang relatif singkat, yakni ketika calon muallaf mengambil 
keputusan untuk memeluk Islam dan mewujudkannya dengan mengikrarkan syahadat. Proses ini menandai perubahan status kegaamaan dari agama semula menuju Islam. Perubahan status keagamaan ini melibatkan adanya kesadaran internal muallaf bahwa dirinya telah menjadi seorang muslim. Kelegaan, kebahagian, ketentraman dan kedamaian merupakan emosi khas yang dirasakan oleh para muallaf setelah melakukan konversi agama.

Proses konversi agama yang dilewati muallaf dilatarbelakangi oleh pertimbangan yang berbeda-beda. Setelah ia berikrar mengucapkan dua kalimat syahadat, tidak berarti bahwa kecemasannya telah hilang sama sekali, karena keraguan akan kemampuan dirinya pun masih menjadi beban pikirannya. Iman dan mental muallaf di masa konversi agama belumlah kuat, sehingga perilaku keagamaannya dimasa konversi agama berkaitan dengan dua aspek dasar, yakni penyesuaian diri dan konflik (Mulyono, 2007: 40).

\section{Penyesuaian diri}

Secara umum terdapat 4 dimensi penyesuaian diri yang dilakukan para muallaf paska konversi agama, yaitu;

1) Dimensi dogmatis, dimensi ini muallaf diharapkan mampu menyesuaikan diri dengan prinsip keimanan (faith) dan ajaran dasar agama yang baru, termasuk yang bersifat ghaib seperti konsep dosa, surga, neraka, juga yang bersifat doktrinal. Penyesuain secara dogmatis bukanlah hal yang mudah dilakukan oleh mualaf karena melibatkan proses rekonstruksi struktur keyakinan dan afeksional. Misalnya, ustadz Yusuf sebagai pemateri kajian aqidah berupaya melakukan rekonstruksi terhadap dogma muallaf atau dogma yang dibentuk oleh agama lama muallaf. Kasus subjek penelitian yang muallaf semuanya mempertanyakan konsep Dogma Ketuhanan Trinitas. Ustadz Yusuf yang dulunya seorang muallaf juga pernah mengalami hal yang sama dengan subjek sebelum melakukan konversi agama. Ustadz yusuf memberikan penjelasan secara panjang lebar dengan berdasarkan al Kitab bahwa intinya Dogma Trinitas merupakan misteri yang tidak bisa dimengerti akal sehat dan disamping itu Dogna Trinitas tidak didukung satupun ayat dalam Injil.

2) Dimensi ritual, Dimensi ritual merupakan bentuk penyesuaian diri yang diwujudkan dalam bentuk perilaku keagamaan atau ibadah sebagai bentuk ketaatan kepada Tuhan, misalnya sholat, puasa, dan membayar zakat. Ritual keagamaan pada agama sebelumnya bisa jadi sangat berbeda dengan ritual dalam Islam, baik dari segi intensitas, tata cara ibadat ataupun pengalaman (experience). Muallaf membutuhkan proses belajar dan pendampingan, penjelasan tentang manfaat dan makna ibadah juga 
penting dijelaskan pada muallaf untuk menumbuhkan motivasi instrinsiknya.

Seperti yang terjadi pada muallaf subjek penelitian ketika peneliti wawancarainya awalnya ia merasa stress untuk melakukan sholat karena bagi subjek bacaan yang dibaca harus arab, melihat tulisannya saja menurut subjek membuat pusing apalagi membacanya, akan tetapi setelah memperoleh bimbingan dari ustadz yang mengajar di Pusat Rehabilitasi Aqidah subjek merasa bahwa sebenarnya belajar membaca Arab itu menyenangkan dan tidak seperti subjek bayangkan.

Subjek penelitian muallaf yang lain juga menceritakan ketika di agama lamanya subjek merasa kurang puas dan kegersangan rohani jika hanya beribadah sekali dalam seminggu dan subjek membandingkan justru ketika dalam Islam subjek merasa ketenangan dan ketentraman jiwa bisa beribadah sehari lima kali, apalagi setelah subyek mendapatkan materi di Pusat Rehabilitasi Aqidah tentang keutamaan-keutamaan dari ibadahibadah yang subjek lakukan, subjek semakin tambah semangat dalam mengerjakan.

3) Dimensi pengetahuan, Agama berisi sekumpulan ajaran dan pedoman yang mengatur para pemeluknya, baik dalam interaksi secara vertikal dengan Tuhan atau sesama manusia. Penyesuaian diri dalam aspek pengetahuan bertambah seiring dengan bertambahnya informasi dan proses belajar tentang agama. Penyesuaian diri seseorang muallaf pada dimensi pengetahuan akan membantu subjek untuk memilki pedoman dan kerangka untuk mengarahkan perilaku yang dilarang, dianjurkan atau diperintahkan dalam agama.

Wawancara dengan subjek penelitian didapatkan informasi bahwa sebelum melakukan konversi ke Islam subjek paling menyukai memakai pakaian yang mengumbar aurat atau pakaian seksi bahkan subjek berpikiran jadi seorang wanita di agama Islam itu seperti ninja pasti merasakan panas dan gerah. Akan tetapi setelah subjek memeluk Islam dan mendapatkan penjelasan tentang pakaian wanita dalam Islam, saat ini subyek sudah memakai pakaian sesuai tuntunan Islam bahkan subjek merasa kenyamanan tidak seperti yang subjek bayangkan ketika masih memeluk agamanya dulu.

Subjek penelitian yang lain juga menceritakan dulu ketika masih dalam agama Kristen sering mengkonsumsi daging Babi apalagi suaminya seorang pendeta sehingga ketika jamuan misa biasanya dihidangkan daging Babi, akan tetapi setelah mendapatkan penjelasan tentang haramnya 
daging Babi dalam Islam saat ini subyek sudah tidak memakannya lagi.

4) Dimensi interaksi social, Para muallaf yang mengikuti bimbingan dan konseling Islam di Pusat Rehabilitasi Aqidah, bukan hanya sekedar belajar secara kognitif, tetapi juga belajar berinteraksi dengan sesama muallaf dalam kehidupan sehari-hari. Bahkan setiap akhir pekan mereka diajak praktek dakwah lapangan oleh para pembimbing. Praktek dakwah lapangan merupakan kegiatan kunjungan ke desa-desa binaan untuk memberikan kajian rutin untuk masyarakat.

Bagi muallaf dalam belajar beradaptasi dengan lingkungan yang baru dan dalam menjalankan ajaran Islam diperlukan dukungan dari teman, keluarga, bahkan lingkungan sekitar melalui interaksi sosial. Hal itu mempermudah muallaf dalam pemantapan agama barunya. Ini dirasakan oleh subjek penelitian yang sampai sekarang masih aktif mengikuti praktek dakwah lapangan.

\section{Konflik}

Konflik terjadi pasca melakukan konversi agama. Dilihat dari sumbernya konflik pasca konversi agama bersumber secara internal dari pribadi muallaf dan secara eksternal terutama berupa reaksi dari orang tua, keluarga, pemuka agama dan komunitas pada agama semula.
Konflik internal yang dirasakan seorang muallaf biasanya berupa rasa adanya perasaan takut yang berlebihan, bimbang, meragukan keputusan yang sudah dibuat, takut membuat komitmen dan rasa bersalah karena menghindar dari tanggungjawab atas konsekuensi tindakan, misalnya ketika harus berbohong pada pasangannya atau terpaksa melakukan misa agar keislamnnya tidak terungkap. Konflik internal juga berbentuk dilema, terutama ketika seorang muallaf dihadapkan pada pilihan-pilihan sulit yang muncul bersamaan dan saling bertentangan, misalnya ketika diminta memilih antara berpisah dengan keluarganya atau komitmennya pada agama Islam. Hasil wawancara terhadap subjek penelitian menceritakan bahwa ketika awal menjadi muallaf dilakukannya secara sembunyi-sembunyi karena takut pada suaminya.

Konflik yang bersumber eksternal berupa reaksi penetangan, penolakan dan ketidaksetujuan atas tindakan konversi agama yang dilakukan muallaf, hal ini bisa diwujudkan dalam bentuk anacaman pengusiran, pemutusan hubungan finansial, pemaksaan agar kembali pada agama semula (koersi), termasuk secara verbal maupun bentuk tindakan fisik seperti pemukulan. Reaksi sosial lewat pengacuhan, cemoohan, gunjingan juga merupakan reaksi sosial yang menimbulkan ketegangan bagi subjek. 
Konflik ini juga dialami oleh subjek penelitian yang lain ketika orang tuanya tahu bahwa subyek melakukan sholat maka orang tuanya menjadi marah, melakukan kekerasan terhadap subyek bahkan mengusir untuk pergi dari rumah. Muallaf juga dihadapkan pada kondisi ketika mereka harus menanggung konsekuensi dan bertanggungjawab atas tindakan yang dilakukan, reaksi sosial yang diterima oleh muallaf pada akhirnya harus dihadapi dan diselesaikan oleh muallaf. Faktor yang mempengaruhi proses prilaku keagamaan subjek penelitian setelah masa konversi dipengaruhi oleh adanya penerimaan diri, inisiatif dan motivasi internal untuk terus melakukan perbaikan diri, keterampilan dalam mengkomunikasikan perasaan dan pendapat kepada orang lain, strategi koping yang dipakai untuk mengatasi konflik, kehendak bertanggungjawab atas konsekuensi tindakan, tingkat ancaman dan tekanan eksternal yang diterima, serta tingkat dukungan sosial yang diperoleh subjek. Keberhasilan proses koping akan membantu subjek keluar dari ketegangan dan membawa perasaan yang positif dan berharga, seperti keyakinan, kepuasan dan kebahagiaan.

Kegagalan koping yang dilakukan akan membuat tingkat ketegangan, stress muallaf meningkat sehingga menimbulkan rasa frustrasi, kekecewaan, perasaan inferior dan putus asa. bertanggungjawab merupakan sebuah perjuangan muallaf untuk membuat orang lain menghormati keputusan konversi yang dilakukan, mempertahankan prinsip yang diyakini. Kombinasi dari strategi koping yang tepat dan kehendak bertanggungjawab akan membuat muallaf mampu menghadapi konflik dan mengatasinya.

Seberapa besar tingkat tekanan eksternal (ancaman) dan internal yang diterima muallaf, menentukan tingkat konflik yang dialami muallaf. Kemampuan muallaf dalam mengatasi masalah, tekanan dan konflik setelah bersyahadat, sangat dipengaruhi oleh seberapa jauh muallaf telah melakukan upaya penyesuaian dalam dimensi dogmatis, ritual, dan interaksi sosial. Keseluruhan proses ini tampaknya membuat struktur keyakinan dalam diri muallaf mengalami proses "keterbukaan" (permeability) dan "penataan ulang" (reconstruction), sehingga perilaku, pola pikir (rigidity), termasuk karena pengaruh dogma agama lama dan kepatuhan yang tanpa syarat akhirnya perlahan-lahan mulai mengarah pada proses penyempurnaan.

Dampak Bimbingan dan Konseling Islam Terhadap Perilaku Keagamaan Muallaf.

Penelitian ini yang dimaksud perilaku keagamaan muallaf adalah muallaf mempunyai keteguhan iman, ketaatan dalam beribadah dan berkepribadian yang baik atau akhlak 
mulia setelah mendapatkan bimbingan dan konseling Islam di Pusat Rehabiltasi Aqidah.

\section{Keteguhan iman}

Peneliti mendapatkan data bahwa semua subjek penelitian ketika peneliti mewawancarai mengungkapkan bahwa setelah mengikuti bimbingan dan konseling Islam perilaku keagamaanya bertambah sangat baik. Menurut subjek bimbingan dan konseling Islam dengan model asrama memudahkan muallaf untuk belajar setiap saat, selain itu juga mempercepat seorang muallaf untuk bisa menyesuaikan diri terhadap keyakinan atau agama barunya.

Misalnya, masalah keyakinan atau aqidah semua subjek merasakan bahwa materi perbandingan agama yang diberikan oleh pembimbing semakin memantapkan keyakinan pada agama yang barunya yaitu Islam, karena materi ini membantu merekonstruksi struktur keyakinan lamanya. Selain itu materi perbandingan agama bisa menghilangkan kebingungan, kegalauan dan kegundahan subjek berkaitan konsep agama lamanya seperti dogma trinitas, dengan mengkaji dan membandingkan akhirnya subjek mendapatkan jawaban yang ilmiah dan bersumber dari kitab suci.

\section{Ketaatan dalam ibadah}

Subjek menceritakan ketika sebelum mengikuti bimbingan dan konseling Islam dalam hal ibadah harian masih belum rutin karena beberapa sebab, misalnya masih belum hafal bacaan sholat, membaca qur'an juga belum lancar. Subjek menambahkan ceritanya bahwa dengan mengikuti program bimbingan konseling Islam, subjek merasa terbantu untuk belajar tatacara sholat dan menghafal bacaan-bacaan sholat serta mengetahui keutamannya sehingga saat ini semua subjek sudah bisa melaksanakan sholat secara tertib dan sudah hafal bacaannya serta semangat untuk mengerjakannya. Menurut penuturan subjek dengan melaksanakan ibadah-ibadah harian seperti sholat, baca Qur'an bisa membuat ketentraman jiwa dan menghilangkan stres.

\section{Kepribadian yang baik atau akhlak mulia}

Hasil wawancara dengan subjek didapatkan informasi bahwa subjek yang perempuan awal melakukan konversi ke Islam belum memakai pakaian yang menutup aurat secara sempurna tetapi setelah mendapatkan materi tentang pakaian perempuan dalam Islam akhirnya subjek dengan kesadaran sendiri menutup auratnya dengan sempurna. Materi tentang akhlak yang diberikan oleh pembimbing bisa merubah secara pelan-pelan kepribadian subjek, misalnya subjek menjadi senang 
bersedekah, membantu tetangganya yang kesusahan. Subjek menceritakan bahwa motivasi melakukan kebaikan karena diagama Islam mendapatkan pahala.

\section{PENUTUP}

\section{Kesimpulan}

Berdasarkan hasil penelitian dan pembahasan di atas, peneliti menyimpulkan bahwa model bimbingan konseling Islam terhadap muallaf menggunakan bentuk konseling spiritual atau religius (Spiritual Counseling). Metode yang diterapkan dalam praktek bimbingan dan konseling Islam menggunakan 3 metode yaitu metode direktif, non direktif dan metode elektif dan dimulai sejak calon muallaf sebelum melakukan konversi sampai pasca konversi agama dengan sistem berasrama.

Bimbingan dan konseling Islam memberikan dampak sangat positif terhadap perilaku keagamaan muallaf, karena setiap muallaf yang mengikuti program bimbingan dan konseling Islam keyakinannya dengan agama baru semakin mantap dan pengetahuan agama Islamnya semakin bertambah sehingga ketaatan menjalankan ibadahnya semakin meningkat dan akhlaknya juga terbina sehingga tercermin dari kepribadiannya dalam kehidupan sehari-hari, misalnya muallaf perempuan cara busananya yang sudah syar'i menutup aurat, muallaf terbiasa mengucapkan salam dengan sesama muslim.

\section{Saran}

Dari hasil penelitian di atas ada beberapa rekomendasi yang ingin peneliti sampaikan diantaranya sebagai berikut; (1) perlunya dibuatkan standarisasi oleh yang pihak berwenang yaitu Departemen Agama dalam melakukan pembinaan terhadap muallaf karena selama ini belum ada standarisasi tentang pembinaan muallaf sehingga lembaga atau organisasi yang melakukan pembinaan muallaf masih berjalan sendiri-sendiri sesuai konsep yang dibuat oleh lembaganya. (2) adanya sinergi antara lembaga atau ormas Islam dalam pembinaan muallaf sehingga masalahmasalah yang dihadapi para muallaf cepat tertangani dengan baik dan tidak ada muallaf yang terlunta-lunta karena masih minimnya kepedulian umat Islam. Saat ini yang terjadi setelah disyahadatkan biasanya dilepas tanpa pembinaan dan pendampingan. (3) Untuk penelitian sejenis dapat memperdalam penelitian dampak bimbingan konseling Islam terhadap prilaku beragama pada muallaf dari latar belakang agama yang lebih beragam, misalnya dari agama Hindu, Budha, atau aliran kepercayaan.

\section{DAFTAR PUSTAKA}

Mujib, Abdul dan Amin, Samsul Munir. 2010. Bimbingan Dan Konseling Islam. Jakarta: Amzah. 
Ancok, Jamaludin dan Nashori, Fuad. 1995. Psikologi Islam. Yogyakarta: Pustaka Pelajar.

Arikunto, Suharsimi. 2006. Prosedur Penelitian: Suatu pendekatan Praktik. Jakarta: Rineka Cipta.

Atkinson, Rita L. Penerjemah: Nurdjanah Taufiq. 1993. Pengantar Psikologi. Jakarta: Erlangga.

Baharudin. 2004. Paradikma Psikologi Islami. Yogyakarta: Pustaka Pelajar.

Bungin, M. Burhan. 2007. Penelitian Kualitatif : Komunikasi, Ekonomi,Kebijakan Publik, dan Ilmu Sosial Lainnya. Jakarta: Kencana.

Daradjat, Zakiah. 1970. Ilmu Jiwa Agama. Jakarta: Bulan Bintang.

Desmita. 2009. Psikologi Perkembangan. Bandung: Remaja Rosdakarya.

Hikmawati, Fenti. 2012. Bimbingan Konseling. Jakarta: Rajawali Pers.

Jalaluddin. 2010. Psikologi Agama. Jakarta: Grafindo Persada.

Kholida, Ninin. 2007. Proses Pencarian Identitas Diri Pada Remaja Muallaf. Skripsi. Semarang: Fakultas Kedokteran UNDIP.

Lubis, Lahmudin. 2007. Bimbingan Konseling Islam. Jakarta: Hijri Pustaka Utama.
Mubarok, Ahmad. 2002. Konseling Agama Teori dan Kasus. Jakarta: Bina Rencana Pariwara.

Moleong. 2004. Metodologi Penelitian Kualitatif. Bandung: Remaja Rosdakarya.

Miles, M.B. and Huberman, A.M. (1992). Analisis Data Kualitatif. Jakarta: UI Press.

Munawar, Thohari. 1992. DasarDasar Bimbingan dan Konseling Islam. Yogyakarta: UII Pres.

Sutoyo, Anwar. 2013. Bimbingan dan Konseling Islami (Teori dan Praktek).Yogyakarta: Pustaka Pelajar.

Subandi. 2013. Psikologi Agama dan Kesehatan Mental. Yogyakarta: Pustaka Pelajar.

Sukmadinata, Nana Syaodih. 2013. Metode Penelitian Pendidikan. Bandung. Remaja Rosdakarya.

Ridwan, Saftani Muhammad. 2013 Menjawab Keraguan (Penjelasan atas Berbagai Pertanyaan Umat Kristiani Terhadap Islam). Makasar: Arimatea Makasar.

Tim Departemen Agama. 2012. Materi Bimbingan Agama pada Muslim Pemula (Muallaf). Jakarta: Dirjen Bimas Islam Departemen Agama.

Tim Arimatea. 2005. Modul Pelaksanaan Pembinaan dan Pendampingan Muallaf. Jakarta: Forum Arimatea Press. 
Tohirin. 2007. Bimbingan Konseling di Sekolah dan Madrasah. Jakarta: Rajawali Press. . 